\title{
CLINICAL STUDIES OF THE BLOOD VOLUME. I. CLINICAL APPLICATION OF A METHOD EMPLOYING THE AZO \\ DYE “EVANS BLUE" AND THE SPECTROPHOTOMETER
}

\author{
By JOHN G. GIBSON, 2ND, AND WILlIAM A. EVANS, JR. \\ (From the Medical Clinic of the Peter Bent Brigham Hospital and the Department of Medicine. \\ Harvard Medical School, Boston)
}

(Received for publication November 20, 1936)

In the investigation of many clinical problems the determination of changes in the plasma and total blood volume occurring either rapidly or over long periods is of considerable interest. Since the introduction of the dye method by Keith, Rowntree and Geraghty in 1915 (1), several authors: Griesbach (2), Seyderhelm and Lampe (3), Heilmeyer (4), H. P. Smith, (5, 7), Graff and Clarke (6), Uhlenbruck and Leyendecker (8), Brockmann (9) and Sunderman (10) have emphasized the unreliability of the original method for clinical uses. In 1935 Gregersen, Gibson and Stead (11) summarized the errors inherent in the earlier methods and developed a method (12) employing the blue azo dye "T-1824" recommended by Dawson, Evans and Whipple (13) determining the dye concentration of samples with the spectrophotometer. In this paper we will describe a modification (14) of this method used by us for investigation of clinical problems and discuss the method in light of our experience therewith.

\section{METHODS}

The dye solutions used are so opaque that the head of the plunger cannot be seen when the syringe is filled. Lines are engraved on the plunger of a $10 \mathrm{cc}$. glass tipped syringe near the head and on the barrel near the open end in such a way that when these lines are opposed, the head of the plunger is opposite the $10 \mathrm{cc}$. graduation on the barrel. Each syringe is calibrated by weight of distilled water contained when filled to the tip. Accurate delivery of dye in amounts from $3 \mathrm{cc}$. to $10 \mathrm{cc}$. is thus assured. Blood for serum is delivered into $6 \mathrm{cc}$. pyrex tubes, a light coating of thin liquid petrolatum being used to prevent adherence of the clot to the tube.

Hematocrit tubes are calibrated to contain $4 \mathrm{cc}$. and graduated into ten volumetrically equal divisions numbered 1 to 10 from the bottom of the tube; these divisions are further graduated by linear measurement into 10 equal subdivisions. A 1.5 per cent aqueous solution of recrystallized potassium oxalate is used as an anticoagulant, the tubes being filled to the graduation numbered 2. Blood is run directly from the syringe into the tubes to the graduation numbered 10 , and mixed with the oxalate by inversion.

All syringes used for the withdrawal of blood must be dry. Needles, syringes, etc., are sterilized by autoclaving.

Preparation of dye solutions and determination of standard values

The same lot of T-1824 has been used throughout our investigation. This dye now called "Evans Blue," after Dr. H. M. Evans, was obtained from the Eastman Kodak Company. It is free from impurities, and is the same used by Dawson, Evans and Whipple (13) in 1920, as proved by its identical spectrophotometric absorption curve. It has the following structural formula:
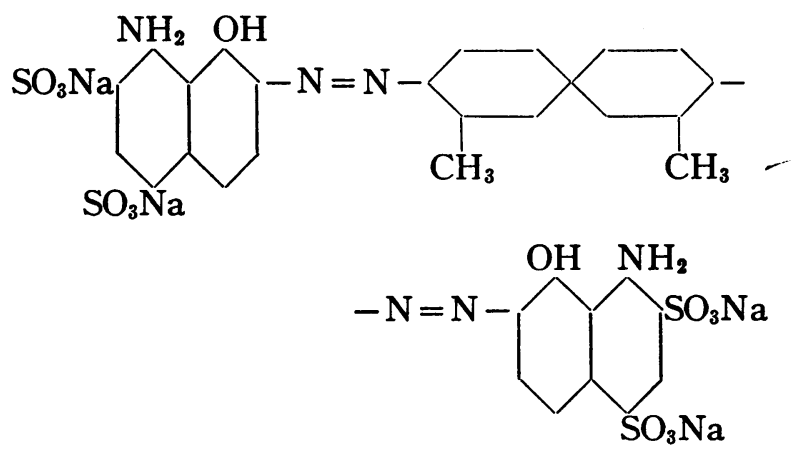

Dye solutions are made up in freshly distilled water and filtered through a Jena sintered glass filter type 3-G-3. Neutral glass ampoules are 
filled with $5 \mathrm{cc}$. or $10 \mathrm{cc}$. amounts, sealed and autoclaved. Solutions are not buffered. Prepared in this way no precipitation has been observed over periods of a year. A fresh ampoule is opened for each determination.

Standards are prepared in concentrations as shown in Table I. A fresh ampoule is opened for each standardization. A dye free serum blank for spectrophotometric reading is prepared by adding $0.2 \mathrm{cc}$. of normal saline to 1.8 cc. of clear serum. ${ }^{1}$ An initial dilution in 0.85 per cent saline of the dye used for injection to one-tenth of the final dilution is made, and standards are prepared in triplicate by adding $0.2 \mathrm{cc}$. of the initial dilutions to $1.8 \mathrm{cc}$. of the same serum used in making the blank. The accepted value is taken as the average of the spectrophotometric readings of the three standards at wavelength of $6200 \mu \mu$ using cells $20 \mathrm{~mm}$. in depth.

Table I shows the standard values obtained for 9 lots of dye so prepared. The variations encountered in individual standardizations, being about plus or minus 1.5 per cent, are within the limit of error of the technique for making up standards and of spectrophotometric reading. The optical properties of the dye are constant when prepared in the manner described. This procedure eliminates the preparation of a standard for each determination, the standard value for each lot of dye being used for the calculation of plasma volume in all determinations made with that lot.

\section{PROCEDURE}

All studies are carried out with patients under basal conditions. In many instances, blood volume determinations were accompanied by measurements of venous pressure by the direct method described by Evans (15) and blood velocity rates by the intravenous injection of "Decholin" as described by Winternitz, Deutsch and Brüll (16).

\section{Single volume determination}

A vein in the antecubital region ${ }^{2}$ is punctured, and $7 \mathrm{cc}$. of blood is withdrawn for the dye free sample and a hematocrit. Stasis must be avoided. The dye is then injected

1 For the 0.2 cc. amounts Van Slyke capillary pipettes delivering between the lines were used, and Ostwald pipettes made to deliver between lines for the $1.8 \mathrm{cc}$. amount. Stohl tips gave additional convenience.

2 If venous pressure is measured before the volume determination the needle employed therefore may be used for this sample, and for dye injection.
TABLE I

Standard values of dye solutions

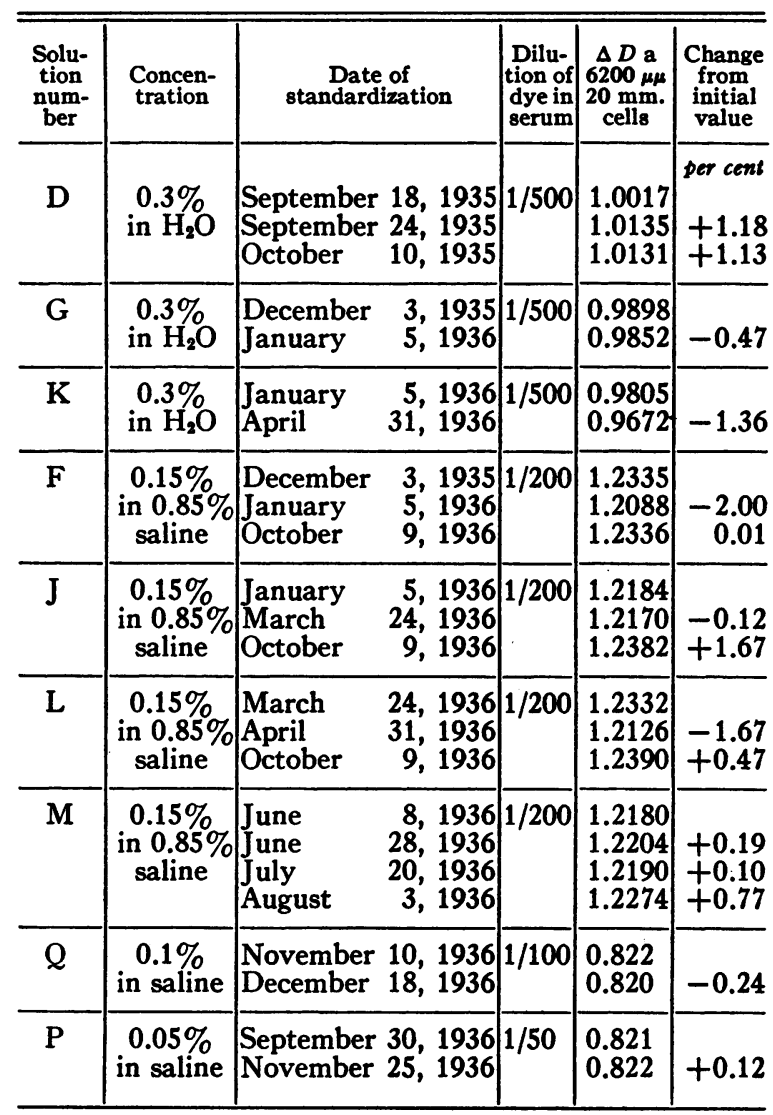

through the same needle, in from thirty to forty seconds, and the syringe is rinsed with blood two or three times to insure delivery of all the dye. This needle is then removed from the vein and discarded. An amount of dye approximating $0.002 \mathrm{mgm}$. per $\mathrm{kgm}$. of body weight is given. A stop watch is started at the beginning of the dye injection, and subsequent samples are timed to the nearest ten seconds. Blood for serum samples and hematocrits are then taken at four or five minute intervals starting ten minutes after the beginning of dye injection, a fresh syringe being used for each sample. These samples can be taken through the same needle, clotting being prevented by injecting small amounts of saline between withdrawals. Dilution of samples with saline is prevented by drawing back blood into the saline delivery syringe before each sample is taken. Three or four hematocrits are obtained at regular intervals. A total of $\mathbf{3 0}$ to $\mathbf{5 0} \mathrm{cc}$. of blood are required for each determination. When sampling is

Blood samples should never be taken through the needle used for the dye injection, as in our experience it is impossible to completely rinse all the dye from the hub or lumen of the needle even with repeated washing with blood or saline. All samples so withdrawn will have erroneously high concentrations of dye. 
complete the blood velocity rate may be determined, the decholin being injected through the same needle used for sampling.

After clot retraction is complete, samples are centrifugalized for five or ten minutes at 2000 r.p.m. The serum is pipetted off and again centrifugalized to completely free it from cells.

Hematocrits are centrifugalized at 3000 r.p.m. for thirty minutes. Corpuscular volume is calculated by the formula:

$$
\text { Per cent cells }=\frac{\text { Reading of packed cells }}{\text { Reading of fluid level }-2.0} .
$$

The dye concentration of serum samples is determined with the Koenig-Martens spectrophotometer. Detailed discussion of the use of this instrument is beyond the scope of this paper; our procedure is as follows.

The absorption cells used are of fused quartz, made in matched pairs with optically ground faces, ${ }^{4} 20$ millimeters in depth. These cells can be emptied with a fine pipette so completely that rinsing between samples is unnecessary.

The spectrophotometer ${ }^{s}$ is provided with a revolving photometer head on the circular scale of which the angular reading obtained when the image fields are matched is read. The initial setting with both cells when empty is such that the angular reading is forty-five degrees. The instrument is set to read at the wavelength $6200 \mu \mu$, the point of maximum absorption of serum solutions of Evans Blue. One cell is then filled with the dye-free and the other with the dyed sample ten readings are taken and averaged, the position of the cells is reversed and ten more readings taken and averaged. The angular readings obtained before and after reversal of the cells will be less than or greater than forty-five degrees depending upon the position of the cell containing the most opaque (dyed) solution. The dye concentration of the samples is then calculated in terms of the net optical density $(\Delta D)$ according to the formula:

$$
\Delta D=\log \text { cotangent } \angle<45^{\circ}+\text { log tangent } \angle>45^{\circ} \text {. }
$$

With the instrument properly aligned the logarithmic values of the two angular readings will be equal.

The $\Delta D$ obtained for each sample is recorded and plotted on coördinate paper and the disappearance slope extrapolated to the ordinate as shown in Figure 1. The volumes are then calculated according to the following formulas:

$$
\begin{array}{cl}
\begin{array}{c}
\text { Plasma volume } \\
\text { in cc. }
\end{array} & =\frac{C \times \Delta D \text { St. } \times D}{\Delta D U}, \\
\text { where } & C=\begin{array}{l}
\text { the number of cc. of dye injected (taken } \\
\text { as the calibration value of the syringe } \\
\text { used), }
\end{array}
\end{array}
$$

\footnotetext{
4 Made by Macalaster Bicknell Company, Cambridge, Mass.

- We have used the Koenig-Martens spectrophotometer made by Schmidt and Haensch, Berlin, Germany.
}

$D=$ the dilution of the dye solution used at which the standard value was determined,

$\Delta D$ St. $=$ the $\Delta D$ of the standard of the dye solution used, as determined in cells of the same depth as used for obtaining $\Delta D U$,

$\Delta D U=$ the $\Delta D$ obtained by extrapolation of the slope of disappearance, as determined from the samples, to intersect the ordinate,

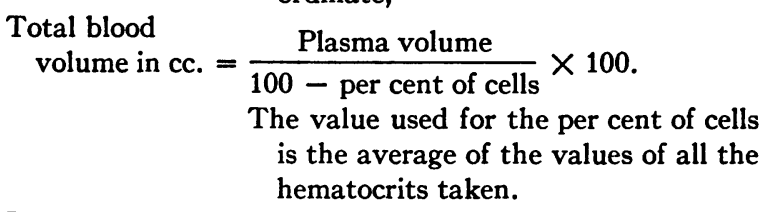

Red cell

volume in cc. $=$ total blood volume-plasma volume.

Due to the method of reading the hematocrits to the top of the white cell layer, the red cell volume as here used includes the volume of the white cells.

\section{Repeated and continuous determinations}

For determining changes in plasma and total blood volume in the same individual, two types of procedure are available, termed by us the "direct" and " indirect" methods. The direct method consists of repeated single determinations in the same subjects at significant intervals, carried out as described above. The amount of dye used for each determination may be reduced if injections are to be made at short intervals.

In the indirect method, the slope of dye disappearance from the blood stream following a single injection is determined during a control period. The deviation in dye concentration of serum samples taken during an ensuing experimental period from the prolongation of the control disappearance slope represents changes in the plasma volume: an increase or decrease in dye concentration of a sample from that of a synchronous point on the disappearance slope indicates a reduction or increase in plasma volume respectively.

Changes in plasma and total blood volume occurring during the experimental period are calculated by the following formula:

$$
\text { P.V.1, 2, etc. }=\frac{\text { P.V. } \times \Delta D \text { sl. }}{\Delta D \text { sp. }}
$$

where P.V.1, 2, etc. $=$ The plasma volume in cc. to be calculated from the $\Delta D$ of serum samples taken during the experimental period,

P.V. = The initial plasma volume in cc. $\Delta D_{\mathrm{sl}}$. $=$ Dye concentration value of point on disappearance slope corresponding to serum sample taken during experimental period, $\Delta D_{\text {sp. }}=$ Dye concentration of serum sample taken during experimental Deriod, 


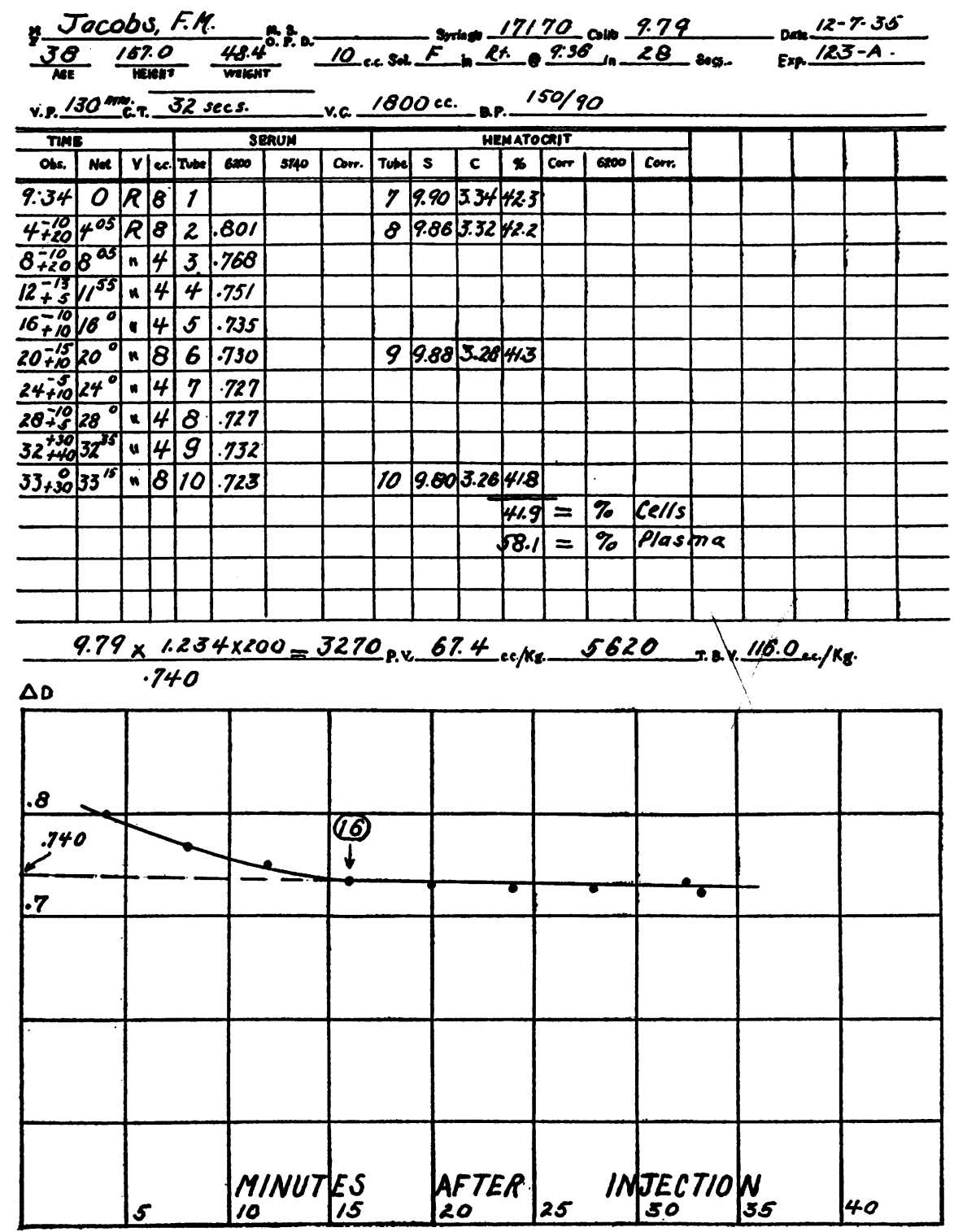

Fig. 1. Standard Protocol for Routine Blood Volume Determinations

The method of extrapolation of the disappearance slope to obtain the optical density on which the calculation of plasma volume is based, and the portions of the curve designated by us " mixing curve," " disappearance slope," and " mixing time" are clearly shown.

T.B.V.1, 2, etc. in cc. $=\frac{\text { P.V.1, 2, oto. }}{100-\text { per cent of cells }} \times 100$, where

Per cent of cells $=$ Hematocrit value of blood sample from serum of which P.V.1, 2, etc. was obtained.

A representative experiment of this type is illustrated in Figure 2.

The indirect method lends itself to the study of changes in plasma and total blood volume occurring over periods of from a few minutes to several hours. When the experimental period is short ( 30 to 60 minutes), a blood volume is carried out in the usual manner except that blood samples for determination of the disappearance slope are taken over a period of time following the dye injection approximately equal to the length of the experimental period. When volume changes are to be followed over a period of several hours the initial volume determination is carried out 12 to 16 hours before the initiation of experimental procedures, from 15 to $30 \mathrm{mgm}$. of dye being injected. Patients are maintained fasting or on a light car- 


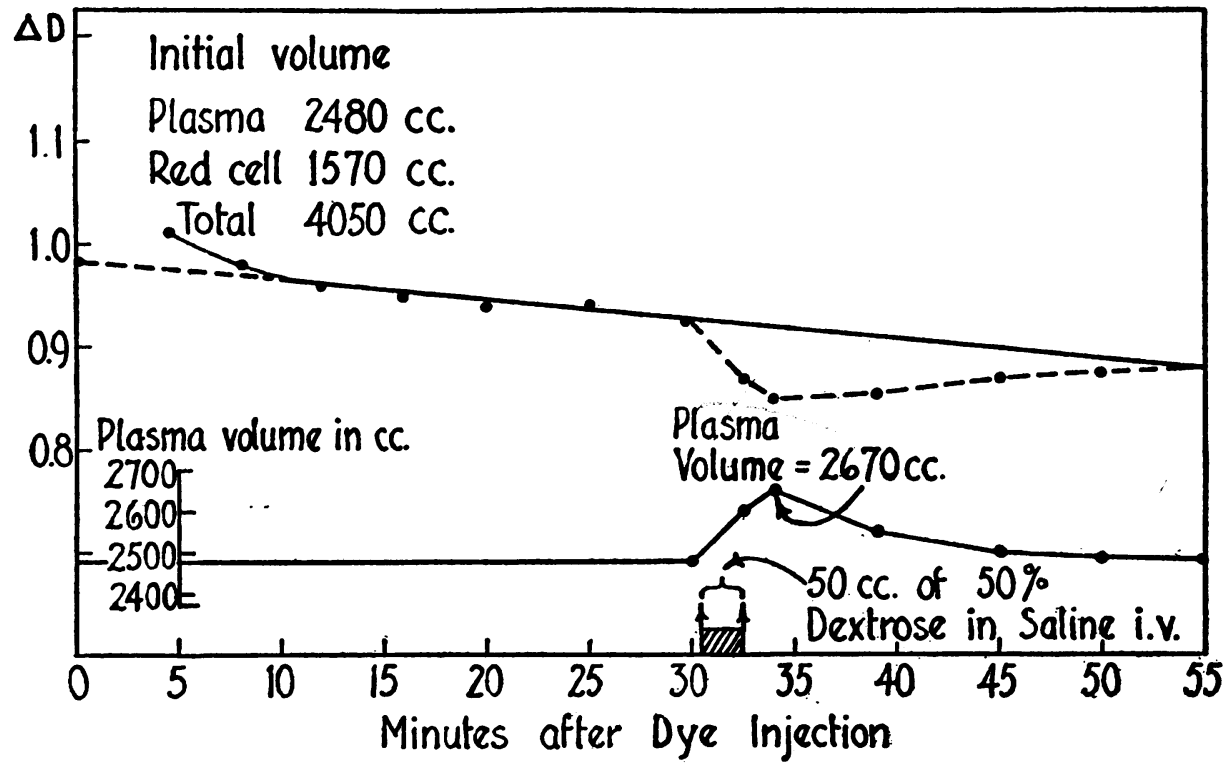

Fig. 2. Changes in Plasma Volume following Rapid Intravenous injection of 50 cc. of 50 Per cent Dextrose Solution in Case 141, Female, Age 20 Years

The control disappearance slope, from the extrapolated value of which the initial volume is calculated and from the prolongation of which changes in volume are calculated is shown.

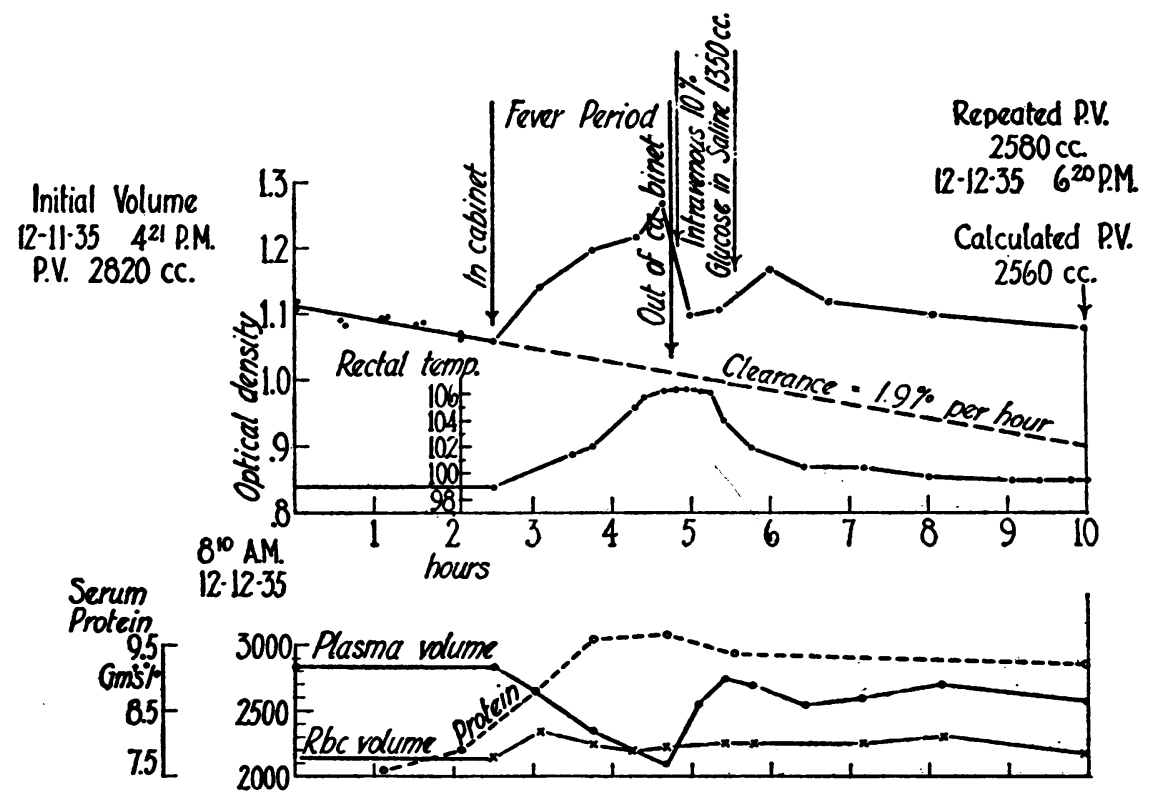

Fig. 3. Changes in Plasma and Red Cell Volume During Artificial Fever in a Paretic, Case 128

The initial volume was determined on the afternoon of the day preceding the experiment, about 16 hours before the zero hour on the chart. The control disappearance slope was determined over two hours and changes in plasma volume calculated from the prolongation of this slope and the initial plasma volume. The extreme concentration of blood during induction of fever with a rapid dilution following a large intravenous injection of 10 per cent dextrose in saline solution is shown, as well as the close agreement of final estimated and redetermined plasma volume at 10 hours. Red cell volumes were calculated from hematocrit and plasma volume values. 
bohydrate diet during the entire observation period. Twelve to 16 hours after dye injection 5 or 6 blood samples for serum samples and hematocrits are taken at 20 to 30 minute intervals by separate venipuncture, for the determination of the control disappearance slope. The experimental procedure is then initiated and blood for serum samples and hematocrits is taken at significant intervals. At the end of the experiment, another volume determination is carried out, from 8 to $12 \mathrm{mgm}$. of dye being injected. Changes in plasma and total blood volume occurring during the experimental period are calculated by the formulae given above. The plasma volume estimated from the dye concentration of the sample taken just prior to the injection of dye for the final volume should equal the final plasma volume. The amount of blood withdrawn in this type of experiment varies from 100 to $200 \mathrm{cc}$. An experiment of this type is illustrated in Figure 3.

\section{CRITIQUE}

\section{Factors affecting the accuracy of single determinations}

A complete discussion of the principles underlying the accuracy of this technique will appear elsewhere. ${ }^{6}$ We are concerned in this paper only with the value of the method as applied by us to the clinical investigation of circulatory and other problems in humans.

\section{Colorimetry}

Estimation of the dye concentration of plasma or serum samples by means of the Dubosq colorimeter has been shown by Griesbach (2), Seyderhelm and Lampe (3) and Gregersen ${ }^{6}$ to be unreliable. If the dye concentration of the standard is less than that of the unknown, the ratio between the readings of the standard and unknown is too low, and the calculated plasma volume falsely high; conversely, if the standard is more concentrated than the unknown, the calculated volume is falsely low. With the method herein described we have encountered clinically plasma volumes from $950 \mathrm{cc}$. to 6000 cc. In determining plasma volumes within this range with the Dubosq colorimeter, if the same amount of dye is injected and the samples are read against a standard of the same concentration in each case (as in the method employed by Keith, Rowntree and Geraghty (1); Hooper, et al. (17); Wollheim (18); and Goldbloom and Libin (19)) large errors will occur. In subjects with low plasma volumes the con-

\footnotetext{
- Gregersen, M. I. In preparation for publication.
}

centration of dye in the sample will be greater than that of the standard and an erroneously high volume value will be obtained, while the reverse condition will be encountered in subjects with large plasma volumes. Thus colorimetry with the Dubosq instrument fails to reveal extreme variations in plasma volume.

This type of error is eliminated with the spectrophotometer, since the absorption cells used are of equal depth, and the dispersion of light in both is equal. Both cells contain the same solvent (serum) in the same concentration, the color value thereof being cancelled; and with the instrument set at the wavelength of maximum absorption of Evans Blue in serum $6200 \mu \mu$ (see Figure 4), the reading obtained accurately determines the difference in color between dye free and dyed samples due to the dye alone.

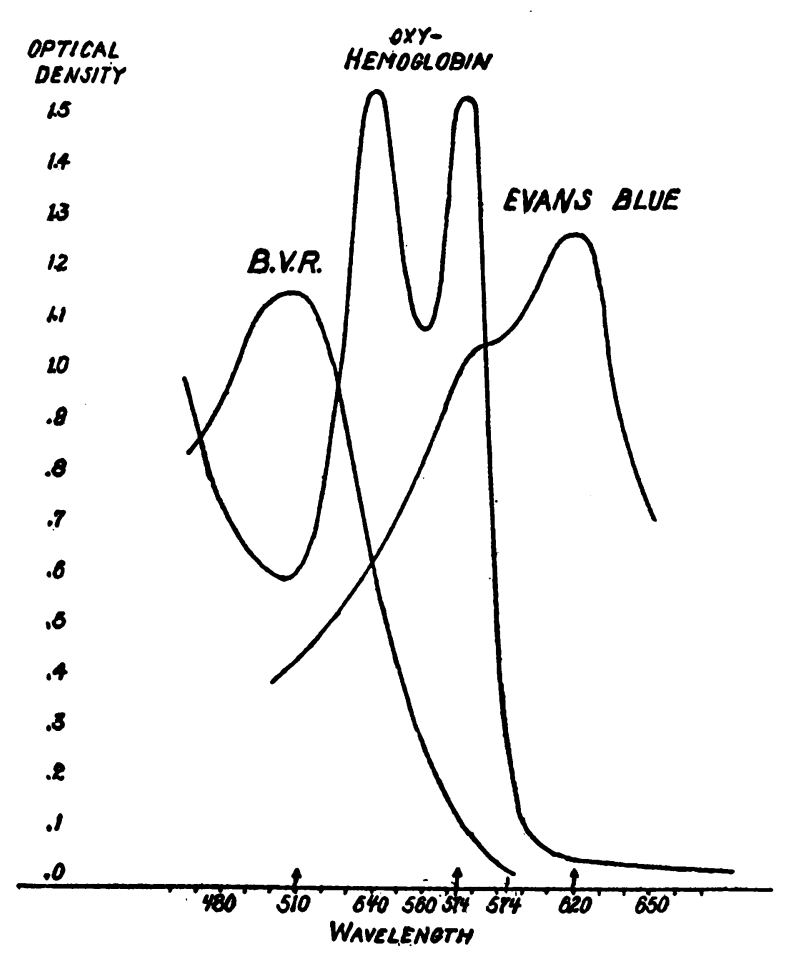

Fig. 4. Spectrophotometric Absorption Curves of Oxyhemoglobin (Human), Brilliant Vital Red aNd Evans Blue in Solution in Serum

These curves and those in Figure 5 were obtained with the Recording Spectrophotometer of the Color Measurements Laboratory of the Massachusetts Institute of Technology. The peak of the absorption curve of oxyhemoglobin occurs at the wavelength $576 \mathrm{~mm}$. with this instrument, and at $574 \mathrm{~mm}$. with the Koenig-Martens Spectrophotometers used by us. 
No error due to residual dye is encountered when repeated determinations are made at short intervals, since here again both cells contain the same concentration of residual dye, and the readings obtained accurately measure the increase in color in the samples taken after the repeated dye injection due to that injection only.

In our experience, small amounts of lipemia do not produce inaccuracies as long as the degree of lipemia remains the same in all samples, but does result in uncorrectable errors if fat is disappearing from the blood stream during the sampling period.

\section{Hemolysis of samples}

Spectrophotometric absorption curves of Evans Blue and oxyhemoglobin (Figure 4) show that the absorption of hemoglobin at the wavelength $6200 \mu \mu$ is little compared to its absorption at the wavelength $5740 \mu \mu$, the point of maximum absorption of oxyhemoglobin. Since both dye and hemoglobin in solution conform to the Beer-Lambert law, for any given degree of hemolysis of a serum sample stained with Evans Blue the per cent of error due to hemoglobin diminishes as the concentration of the dye increases. Thus if large amounts of the blue dye can be injected, as in animal experimentation, the error due to even considerable hemolysis is for practical purposes negligible.

Such large amounts of dye cannot be routinely employed in humans because of the undesirability of vital staining. With the amount of dye used by us, $\Delta D$ values from about 0.4 to 1.2 are obtained and at these concentrations degrees of hemolysis as sometimes encountered even with careful withdrawal of blood may give rise to errors of from 2 to 5 per cent. It is therefore necessary in clinical investigation to have a method for correcting for hemoglobin.

Three possibilities obtain: hemolysis of dye free sample, dyed sample or of both samples. We have determined the ratio of the optical densities of oxyhemoglobin in serum solution at $5740 \mu \mu$ and $6200 \mu \mu$ to be approximately 40 to 1 ; and that of Evans Blue in serum at the corresponding wavelengths to be 0.8 to $1 .^{7}$

These studies were carried out with the recording spectrophotometer of the Color Measurement Laboratory of the Massachusetts Institute of Technology through the courtesy of Professor Arthur C. Hardy.
Based on the correction method of Graff and Clark (6) for oxyhemoglobin and brilliant vital red, correction for hemolysis of either sample is effected by the following formula:

where

$$
D_{2}=\frac{K_{h} A-B}{K_{h}-K_{d}}
$$

$A=$ The $\Delta D$ of the dyed sample read against the dye free sample at $6200 \mu \mu$,

$B=$ The $\Delta D$ of the dyed sample read against the dye free sample at $5740 \mu \mu$,

$H_{1}$ and $H_{2}$ are the $\Delta D$ of oxyhemoglobin read against its solvent hemoglobin free serum at $5740 \mu \mu$ and $6200 \mu \mu$ respectively,

$D_{1}$ and $D_{2}$ are the $\Delta D$ of Evans Blue in hemoglobin free serum read against its solvent at $5740 \mu \mu$ and $6200 \mu \mu$ respectively,

$K_{h}=$ the ratio between the $\Delta D$ of oxyhemoglobin in serum read against its solvent hemoglobin free serum at $5700 \mu \mu$ and $6200 \mu \mu$,

$K_{d}=$ the ratio of the $\Delta D$ of Evans Blue in hemoglobin free serum read against its solvent at $5740 \mu \mu$ and $6200 \mu \mu$.

The derivation of this formula is as follows:

(1) $A=D_{2}+H_{2}$, or $H_{2}=A-D_{2}$.

(2) $B=D_{1}+H_{1}$, or $H_{1}=B-D_{1}$.

(3) $\frac{H_{1}}{H_{2}}=K_{h}$

According to the Beer-Lambert Law constant for any colored solution; we have determined the value of this constant to be $\mathbf{4 0 . 0}$.

(4) $\frac{D_{1}}{D_{2}}=K_{d}$ or $D_{1}=K_{d} \times D_{2}$.

We have determined the value of the constant $K_{d}$ to be 0.8 .

(5) Dividing (1) by (2), $\frac{H_{1}}{H_{2}}=\frac{B-D_{1}}{A-D_{2}}$,

(6) Substituting (3) in (5), $K_{h}=\frac{B-D_{1}}{A-D_{2}}$,

(7) Substituting (4) in (6), $K_{h}=\frac{B-K_{d} \cdot D_{2}}{A-D_{2}}$;

or $\quad K_{h} A-K_{h} D_{2}=B-K_{d} D_{2}$,

then

(8) $K_{d} \cdot D_{2}-K_{h} \cdot D_{2}=B-K_{h} A$,

or $D_{2}\left(K_{d}-K_{h}\right)=B-K_{h} A$,

and

(9) $D_{2}=\frac{B-K_{h} A}{K_{d}-K_{h}}$, or $D_{2}=\frac{K_{h} A-B}{K_{h}-K_{d}}$.

This formula can only be applied when the dye free or at least one of the dyed samples is hemoglobin free. When the dye free sample contains no hemoglobin, correction of all hemolyzed dyed samples is simply made. When the dye free sample is hemolyzed, a non-hemolyzed dyed sample is read against it; the values thus ob- 
tained for $A$ and $B$ are used in the formula and the corrected value for the dyed sample at $6200 \mu \mu$ calculated. The difference between the corrected value so obtained and the actual reading at $6200 \mu \mu$ constitutes the error at that wavelength due to the hemoglobin in the dye free sample.

Should some samples in the series also be hemolyzed, readings against the hemolyzed dye free sample are taken at $6200 \mu \mu$ and $5740 \mu \mu$ and the value determined for the error at $6200 \mu \mu$ due to hemolysis of the dye free sample added to the reading at $6200 \mu \mu$ and the corresponding value for this error at $5740 \mu \mu$ (forty times the amount at $6200 \mu \mu$ ) added to the reading obtained at $5740 \mu \mu$, and these corrected values for $A$ and $B$ are used in the formula.

The dye free sample may be so greatly hemolyzed that the absorption at $5740 \mu \mu$ may be greater in the dye free than in the dyed sample in which case the value obtained for $B$ must be used as an algebraically minus quantity.

\section{Mixing of dye in the blood stream}

Methods in common use are based on the assumption that injected dye is completely mixed in the blood stream in all cases in from three to six minutes and that there is no significant loss of dye from the plasma during the mixing period.

When samples are taken at three or four minute intervals over a period of thirty minutes after dye injection (see Figure 1), the dye concentration of successive samples falls rapidly at first, gradually reaching a constant rate of decrease. The initial rapid fall in concentration is due to mixing of dye in the blood stream, and this portion of the curve is termed by us the "mixing curve"; the subsequent portion in which the fall in concentration is constant, the "disappearance slope"; and the tangent point of these two curves the "mixing time."

Mixing time is related principally to the blood velocity rate as illustrated in Figure 6, in which it is seen that the mixing time of normals (as determined with $3 \mathrm{cc}$. to $10 \mathrm{cc}$. of dye) falls within narrow limits, averaging 7.5 minutes; that of cases of hyperthyroidism is more rapid; while in cases with velocity rates

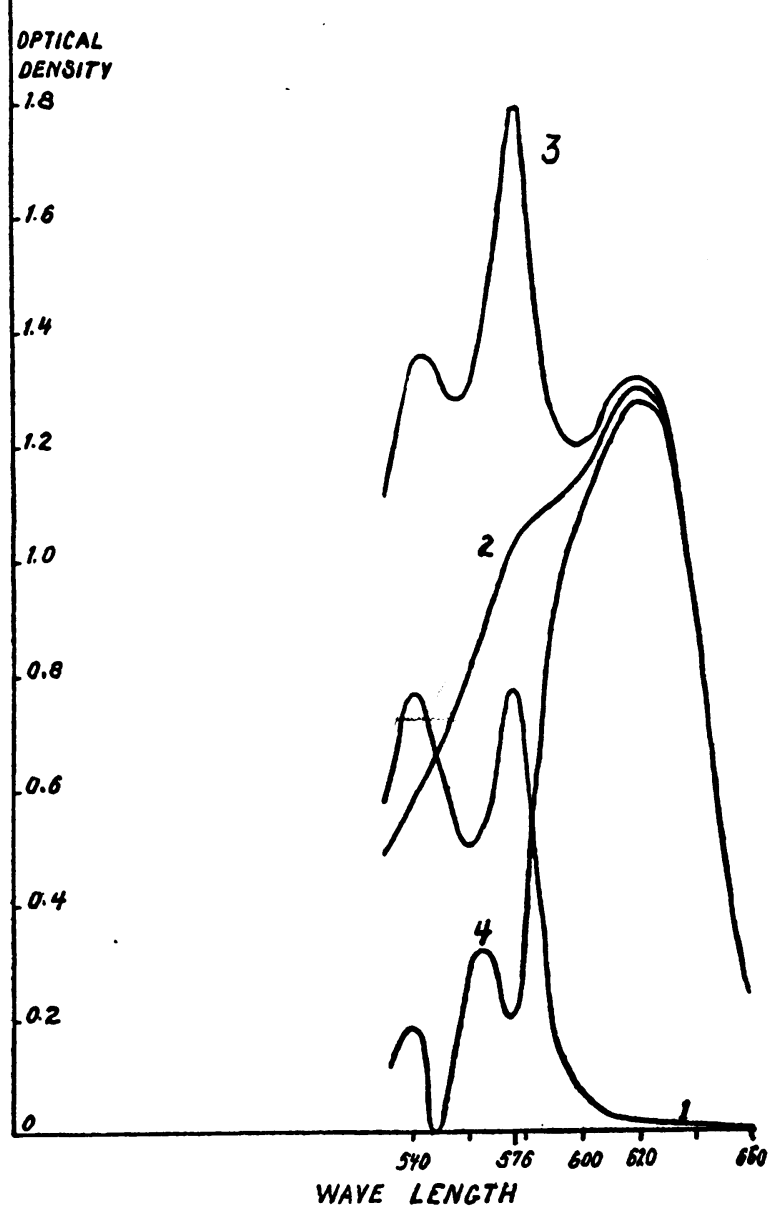

Fig. 5. Spectrophotometric Absorption Curves of Hemolyzed Solutions of Evans Blue

(1) Oxyhemoglobin in solution in hemoglobin free human serum read against its solvent. (2) Evans Blue in solution in hemoglobin free human serum read against its solvent. (3) Evans Blue in same concentration as (2) in solution in serum containing the same concentration of hemoglobin as (1) read against hemoglobin free human serum. (4) Solution (2) read against solution (1).

greater than twenty-five seconds, the normal average mixing time is exceeded; and that when the velocity rate is very slow the mixing time is greatly prolonged.

Figure 7 shows composite mixing curves in four groups of cases: normal, hyperthyroidism, moderate, and severe congestive heart failure. Analysis of these groups shows the degree of error to be encountered when the volume calculation is based on the dye concentration of a single sample taken three minutes after dye injection, as compared to the volume obtained by this 


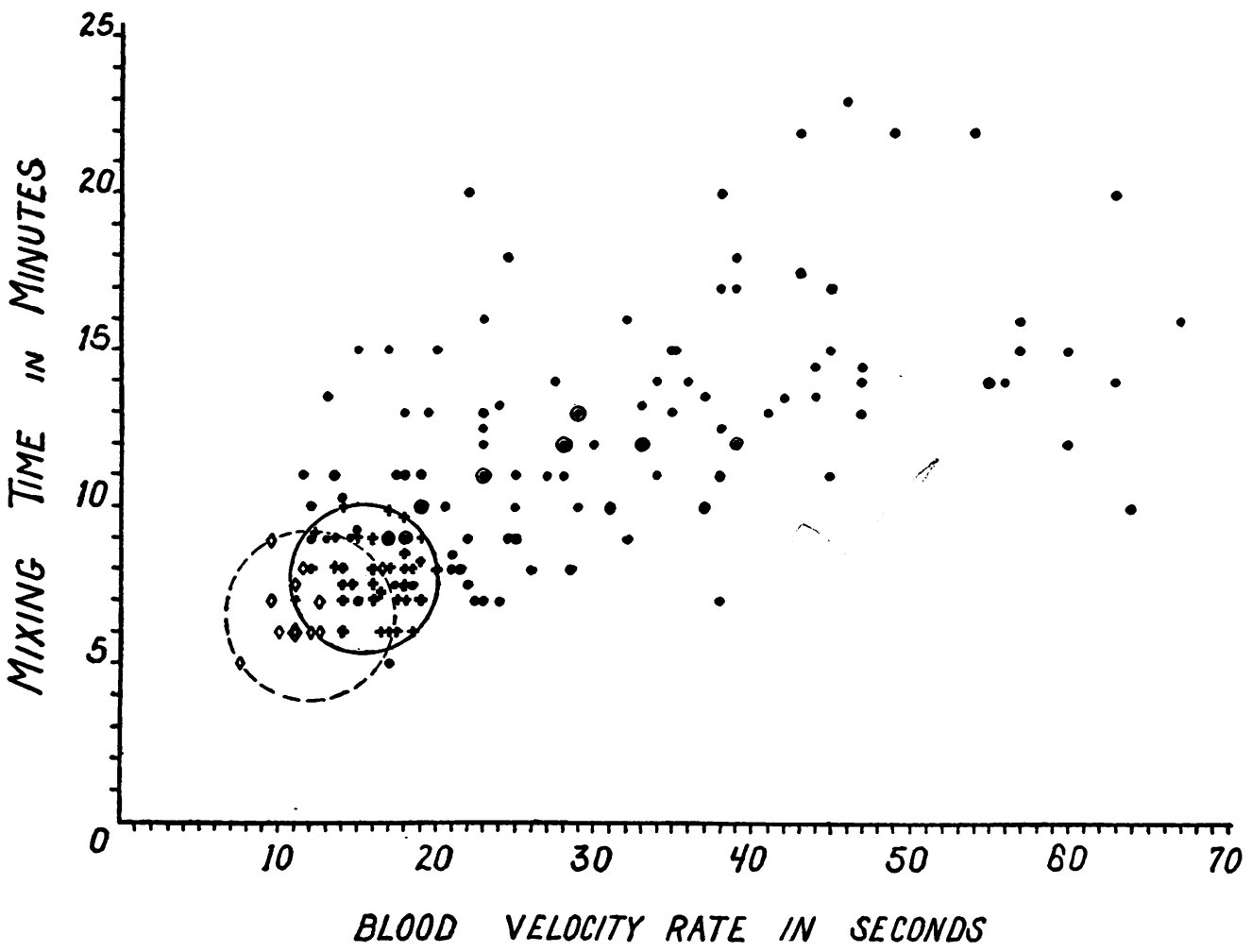

Fig. 6. The Relation of Mixing Time to Blood Velocity Rate as Determined by the Intravenous Injection of " Decholin" in 31 Normal. Patients, 11 with Hyperthyroidism aNd in 60 Determinations in 36 Patients in Varying Stages of Congestive Heart Fallure

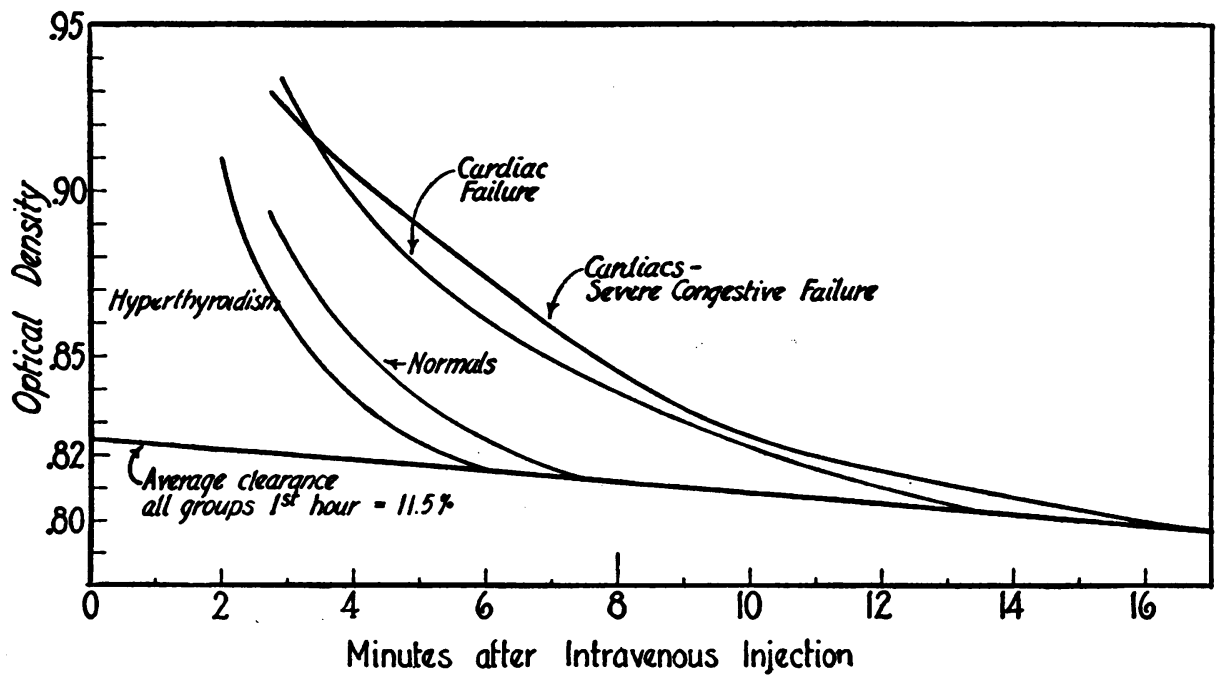

Fig. 7. Composite Mixing Curves, Representing Average Curves of 5 Patients with Hyperthyroidism, 15 Normals, 9 with Moderate and 7 with Severe Congestive Heart Failure 
method to be great. Since the dye is never completely mixed in three minutes, dye concentration of a sample taken at this time is always too high and the error is always in the direction of a falsely low volume. The average error in these four groups is 7.5 per cent for normals, 2.4 per cent for hyperthyroidism, 15.7 per cent for moderate and 19.6 per cent for severe congestive heart failure.

\section{Disappearance of dye from the blood stream}

Dye is removed from the blood stream principally by phagocytosis in the reticulo-endothelial system. It is not found in the urine of individuals with normal kidneys. We have been unable to demonstrate by spectrophotometric examination the presence of Evans Blue after intravenous injection in the edema, pleural or ascitic fluid of patients with congestive heart failure; in the ascitic fluid of patients with cirrhosis of the liver; in the edema, pleural or ascitic fluid of dogs rendered edematous by plasmapharesis; in the cerebrospinal fluid of a paretic patient; or in the fetal cord blood serum or amniotic fluid of a pregnant woman delivered by Caesarean section.

While we have not attempted to recover
Evans Blue from thoracic lymph, the observation of Smith (20) of the presence of brilliant vital red, a related colloidal dye, in thoracic lymph shortly after intravenous injection, indicates that dye may diffuse into lymph during the observation period. Plasma volume determinations based on the dye concentration of a single sample, even though taken when mixing is complete may accordingly be in error to the extent of this loss into the lymph.

In the method herein described the plasma volume calculation is based upon a value obtained by extrapolation of the disappearance slope to the time of injection. This gives the dye concentration that would theoretically obtain were all the injected dye to be mixed with all the circulating blood before any blood has been withdrawn or any dye has disappeared from the blood stream. This procedure minimizes errors due to diffusion of dye into lymph, and variations in initial rate of mixing in and disappearance from the blood stream.

\section{Hematocrit}

The dye method is essentially for the determination of the plasma volume, and the validity of the total blood volume calculation, based on hematocrits, rests on the assumption that hema-

TABLE II

Repeated basal plasma and total blood volume determinations in individuals over varying lengths of time

\begin{tabular}{|c|c|c|c|c|c|c|c|c|c|c|c|}
\hline \multirow{2}{*}{$\begin{array}{l}\text { Subject } \\
\\
\begin{array}{l}\text { W. A..... } \\
\text { W. A.... }\end{array}\end{array}$} & \multirow{2}{*}{$\begin{array}{c}\begin{array}{c}\text { Experi- } \\
\text { ment } \\
\text { number }\end{array} \\
\\
46 \mathrm{~A} \\
46 \mathrm{C}\end{array}$} & Date & \multirow{2}{*}{$\begin{array}{c}\text { Age } \\
\\
y e a r s \\
28 \\
29\end{array}$} & \multirow{2}{*}{$\begin{array}{l}\text { Sex } \\
\\
M\end{array}$} & \multirow{2}{*}{$\begin{array}{c}\text { Weight } \\
\text { kgm. } \\
\begin{array}{l}71.8 \\
71.6\end{array}\end{array}$} & \multirow{2}{*}{$\begin{array}{c}\begin{array}{c}\text { Amount } \\
\text { of Evans } \\
\text { Blue given } \\
\text { intra- } \\
\text { venously }\end{array} \\
\begin{array}{c}m g m . \\
18 \\
9\end{array}\end{array}$} & \multicolumn{2}{|c|}{ Plasma volume } & \multicolumn{2}{|c|}{ Total blood volume } & \multirow{2}{*}{\begin{tabular}{|} 
Hematocrit \\
\\
46.7 \\
42.9
\end{tabular}} \\
\hline & & $\begin{array}{l}23,1935 \\
21,1936\end{array}$ & & & & & $\begin{array}{c}c c . \\
2985 \\
3170\end{array}$ & $\begin{array}{c}\text { cc. per } \mathrm{kgm} . \\
41.6 \\
44.3\end{array}$ & $\begin{array}{c}c c . \\
5600 \\
5540\end{array}$ & $\begin{array}{c}\text { cc. per } \mathrm{kgm} . \\
78.1 \\
77.4\end{array}$ & \\
\hline $\begin{array}{l}\text { A. } H \ldots \ldots \\
\text { A. H..... }\end{array}$ & $\begin{array}{l}82 \mathrm{~A} \\
82 \mathrm{~B}\end{array}$ & $\begin{array}{ll}\text { September } & 18,1935 \\
\text { June } & 17,1936\end{array}$ & $\begin{array}{l}30 \\
30\end{array}$ & $\begin{array}{l}\mathbf{M} \\
\mathbf{M}\end{array}$ & $\begin{array}{l}62.7 \\
63.3\end{array}$ & $\begin{array}{l}10 \\
15\end{array}$ & $\begin{array}{l}2610 \\
2530\end{array}$ & $\begin{array}{l}41.6 \\
39.5\end{array}$ & $\begin{array}{l}4620 \\
4480\end{array}$ & $\begin{array}{l}73.5 \\
70.8\end{array}$ & $\begin{array}{l}43.4 \\
43.0\end{array}$ \\
\hline $\begin{array}{l}\mathrm{J} \\
\mathbf{J} . \mathbf{M} \\
\mathbf{M} . \ldots\end{array}$ & $\begin{array}{l}\text { 196A } \\
196 \mathrm{~B}\end{array}$ & $\begin{array}{lr}\text { January } & 8,1936 \\
\text { February } & 19,1936\end{array}$ & $\begin{array}{l}28 \\
28\end{array}$ & $\begin{array}{l}\mathbf{M} \\
\mathbf{M}\end{array}$ & $\begin{array}{l}73.3 \\
71.0\end{array}$ & $\begin{array}{l}30 \\
30\end{array}$ & $\begin{array}{l}2760 \\
2630\end{array}$ & $\begin{array}{l}37.7 \\
37.0\end{array}$ & $\begin{array}{l}\mathbf{5 3 8 0} \\
\mathbf{5 1 1 0}\end{array}$ & $\begin{array}{l}73.5 \\
71.9\end{array}$ & $\begin{array}{l}48.6 \\
48.6\end{array}$ \\
\hline $\begin{array}{l}\text { J.S...... } \\
\text { J.S..... }\end{array}$ & $\begin{array}{l}\text { 198A } \\
198 B\end{array}$ & $\begin{array}{l}11,1936 \\
15,1936\end{array}$ & $\begin{array}{l}43 \\
43\end{array}$ & $\begin{array}{l}\mathbf{M} \\
\mathbf{M}\end{array}$ & $\begin{array}{l}62.8 \\
61.7\end{array}$ & $\begin{array}{l}30 \\
30\end{array}$ & $\begin{array}{l}2280 \\
2320\end{array}$ & $\begin{array}{l}36.3 \\
37.7\end{array}$ & $\begin{array}{l}3950 \\
3740\end{array}$ & $\begin{array}{l}62.7 \\
60.5\end{array}$ & $\begin{array}{l}42.2 \\
37.7\end{array}$ \\
\hline $\begin{array}{l}\text { J. } \\
\text { J. } \\
\text { B.......... }\end{array}$ & $\begin{array}{l}202 \mathrm{~A} \\
202 \mathrm{~B}\end{array}$ & $\begin{array}{r}22,1936 \\
1,1936\end{array}$ & $\begin{array}{l}44 \\
44\end{array}$ & $\begin{array}{l}\mathbf{M} \\
\mathbf{M}\end{array}$ & $\begin{array}{l}68.7 \\
72.5\end{array}$ & $\begin{array}{l}30 \\
30\end{array}$ & $\begin{array}{l}3020 \\
3030\end{array}$ & $\begin{array}{l}44.0 \\
41.8\end{array}$ & $\begin{array}{l}\mathbf{5 4 0 0} \\
\mathbf{5 3 2 0}\end{array}$ & $\begin{array}{l}78.6 \\
73.3\end{array}$ & $\begin{array}{l}43.0 \\
43.0\end{array}$ \\
\hline $\begin{array}{l}\text { L. S. } \\
\text { L. S.. }\end{array}$ & $\begin{array}{l}86 A \\
86 B\end{array}$ & $\begin{array}{ll}\text { October } & 2,1935 \\
\text { October } & 9,1935\end{array}$ & $\begin{array}{l}23 \\
23\end{array}$ & $\begin{array}{l}\mathbf{M} \\
\mathbf{M}\end{array}$ & $\begin{array}{l}59.6 \\
60.2\end{array}$ & $\begin{array}{l}12 \\
10\end{array}$ & $\begin{array}{l}2340 \\
2360\end{array}$ & $\begin{array}{l}39.2 \\
39.3\end{array}$ & $\begin{array}{l}4180 \\
4200\end{array}$ & $\begin{array}{l}70.2 \\
69.8\end{array}$ & $\begin{array}{l}44.1 \\
43.9\end{array}$ \\
\hline $\begin{array}{l}\text { J. G. G... } \\
\text { J. G. G... } \\
\text { J. G. G... } \\
\text { J. G. G... }\end{array}$ & $\begin{array}{c}1 \\
2 \\
32 \mathrm{~A} \\
132\end{array}$ & $\begin{array}{lr}\text { November } 7,1934 \\
\text { November } 14,1934 \\
\text { May } 26,1935 \\
\text { December } & 19,1935\end{array}$ & $\begin{array}{l}37 \\
37 \\
37 \\
38\end{array}$ & $\begin{array}{l}\mathbf{M} \\
\mathbf{M} \\
\mathbf{M}\end{array}$ & $\begin{array}{l}72.6 \\
72.6 \\
70.4 \\
69.5\end{array}$ & $\begin{array}{l}10 \\
10 \\
12 \\
15\end{array}$ & $\begin{array}{l}3120 \\
3010 \\
2945 \\
3000\end{array}$ & $\begin{array}{l}42.8 \\
41.5 \\
41.8 \\
43.2\end{array}$ & $\begin{array}{l}\mathbf{5 5 3 0} \\
\mathbf{5 3 4 0} \\
\mathbf{5 3 5 0} \\
\mathbf{5 2 8 0}\end{array}$ & $\begin{array}{l}76.3 \\
73.6 \\
76.0 \\
76.1\end{array}$ & $\begin{array}{l}43.8 \\
43.7 \\
41.8 \\
43.2\end{array}$ \\
\hline
\end{tabular}


tocrit values obtained under basal conditions from peripheral blood represent the true cell concentration of blood throughout the body. While there may be differences in corpuscular volume of central and peripheral blood, we feel that the differences observed in hematocrit values as determined by this method are of clinical significance.

\section{Toxicity of Evans Blue}

Gibson and Gregersen (21) in 1935 made comparative studies of the toxicity of brilliant vital red and T-1824 (Evans Blue) when administered intravenously to growing male rats and concluded that both dyes were non-toxic in doses up to $20 \mathrm{mgm}$. per $\mathrm{kgm}$. Our standard dose of $0.002 \mathrm{mgm}$. per $\mathrm{kgm}$. is $1 / 80$ th of the upper limit of safe dosage, and about one-tenth the amount of brilliant vital red $(100 \mathrm{mgm}$. to
$150 \mathrm{mgm}$.) required by earlier methods. With this amount of dye no gross vital staining or immediate or late toxic or untoward effects have been encountered by us in over 300 patients, many of whom have been injected several times.

\section{Factors affecting the accuracy of the direct and indirect methods}

The reliability of the direct method rests on the assumption that the blood volume in the basal state is constant. Findings in 7 normal individuals in whom volume studies under basal conditions were made over periods of from a few days to several months are summarized in Table II. While it is possible that the plasma and total blood volume varies somewhat from day to day, the constancy of the volumes obtained in these subjects under basal conditions leads us to believe that by the direct method changes in

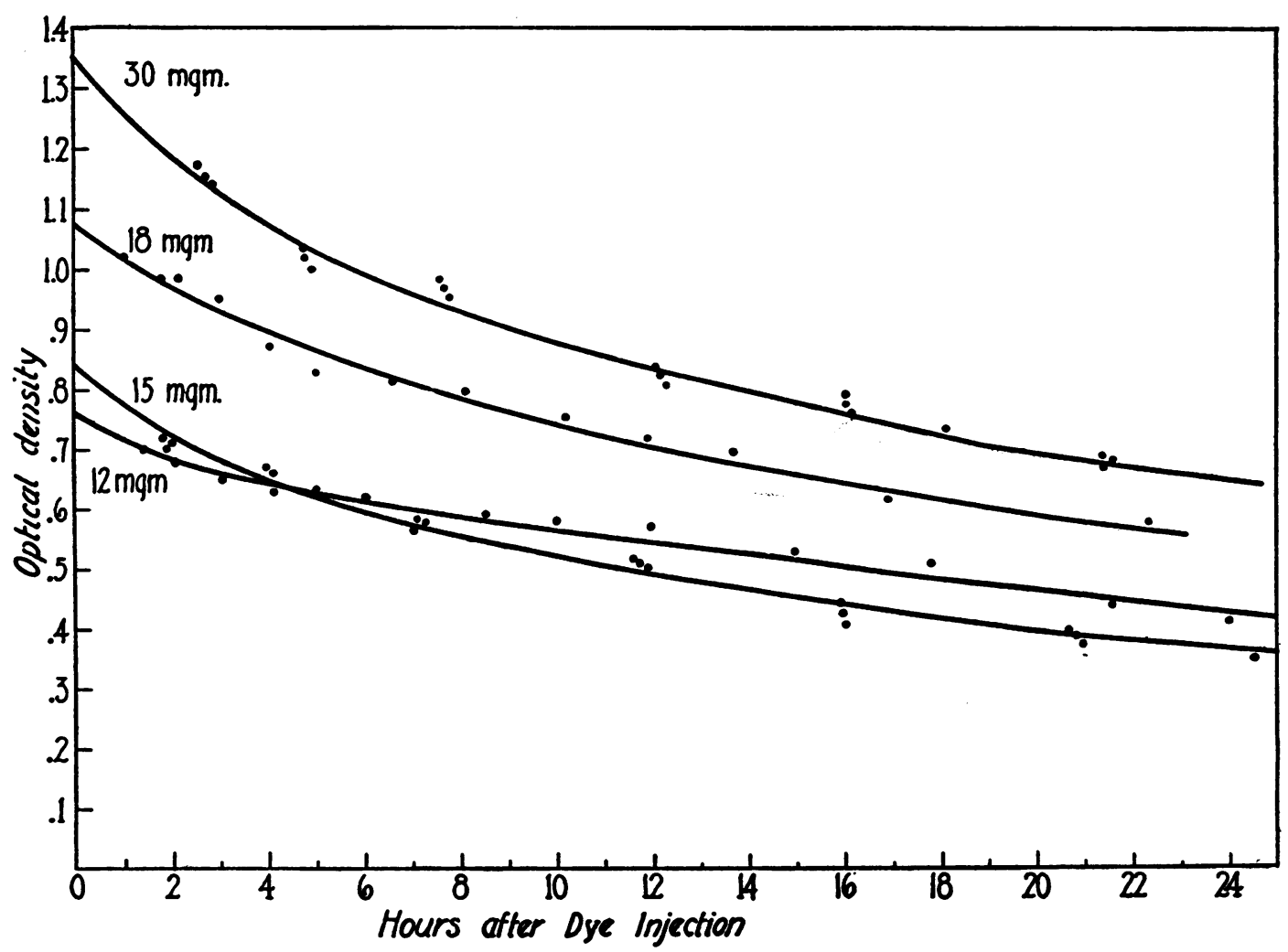

Fig. 8. Disappearance from the Blood Stream of Varying Amounts of Intravenously Injected Evans Blue in 4 Normal Males

The rate of disappearance becomes practically constant from about 12 hours after injection on. In the curves of cases injected with $30 \mathrm{mgm}$. and $15 \mathrm{mgm}$. of dye the progressive fall in dye concentration of serum from serial samples taken at short intervals is shown. Disappearance slopes constructed from these points would be in excess of the prevailing disappearance slope for the 24-hour period. 
excess of 5 per cent of the plasma volume can be reliably measured.

We have studied the disappearance from the blood stream of varying amounts of intravenously injected Evans Blue over 24 hour periods in four normal subjects. They were at complete bed rest and were maintained on a light carbohydrate diet and given water as desired throughout the observation period. An initial blood volume, with different amounts of dye in each case was carried out, and the disappearance of dye from the blood stream thereafter was followed by means of single or multiple blood samples taken at 1 to 3 hour intervals. Results are shown in Figure 8. Table III gives the rates hours later samples for determination of the disappearance slope were taken by separate venipunctures at 20 minute intervals for two hours. The results of these studies are shown in Table IV. The average determined rate of disappearance during the 2-hour period, 16 hours after dye injection in these 10 individuals is 2.20 per cent per hour, which compares well with an average disappearance rate of 2.19 per cent per hour for the 16 to 20 -hour period in the 24hour group. (See Table III.) However, in some instances (Experiments 135 and 229, Table IV) the determined rate of disappearance is in excess of the average hourly rate of disappearance from the time of dye injection, a condition not in

TABLE III

Disappearance from the blood stream of intravenously injected Evans Blue in four normal males

\begin{tabular}{|c|c|c|c|c|c|c|c|c|c|c|c|c|c|c|c|c|c|c|c|}
\hline \multirow{3}{*}{$\begin{array}{c}\text { Experi- } \\
\text { ment } \\
\text { number }\end{array}$} & \multirow{3}{*}{ Date } & \multirow{3}{*}{$\begin{array}{l}\text { Amount } \\
\text { of Evans } \\
\text { Blue } \\
\text { given } \\
\text { intra- } \\
\text { venously }\end{array}$} & \multirow{2}{*}{\multicolumn{2}{|c|}{$\begin{array}{c}\text { Plasma } \\
\text { vol- } \\
\text { ume }\end{array}$}} & \multirow{3}{*}{$\begin{array}{l}\text { Blood } \\
\text { drawn }\end{array}$} & \multicolumn{10}{|c|}{ Hourly disappearance rate (per cent) } & \multirow{3}{*}{$\begin{array}{l}\text { Amount } \\
\text { cleared } \\
\text { in } 24 \\
\text { hours }\end{array}$} & \multirow{3}{*}{$\begin{array}{c}\text { Initial } \\
\Delta D\end{array}$} & \multirow{3}{*}{$\begin{array}{l}\text { Average } \\
\text { dis- } \\
\text { appear- } \\
\text { ance } \\
\text { at } 16 \\
\text { hours }\end{array}$} & \multirow{3}{*}{$\begin{array}{l}\text { Disap- } \\
\text { peared } \\
\text { at } 16 \\
\text { hours }\end{array}$} \\
\hline & & & & & & \multirow{2}{*}{$\begin{array}{c}0 \\
\text { to } \\
1\end{array}$} & \multirow{2}{*}{$\begin{array}{c}1 \\
\text { to } \\
2\end{array}$} & \multirow{2}{*}{$\begin{array}{c}2 \\
\text { to } \\
3\end{array}$} & \multirow{2}{*}{$\begin{array}{c}3 \\
\text { to } \\
4\end{array}$} & \multirow{2}{*}{$\begin{array}{c}4 \\
\text { to } \\
6\end{array}$} & \multirow{2}{*}{$\begin{array}{l}6 \\
\text { to } \\
8\end{array}$} & \multirow{2}{*}{$\begin{array}{l}8 \\
\text { to } \\
12\end{array}$} & \multirow{2}{*}{$\begin{array}{l}12 \\
\text { to } \\
16\end{array}$} & \multirow{2}{*}{$\begin{array}{l}16 \\
\text { to } \\
20\end{array}$} & \multirow{2}{*}{$\begin{array}{l}20 \\
\text { to } \\
24\end{array}$} & & & & \\
\hline & & & Initial & Final & & & & & & & & & & & & & & & \\
\hline $\begin{array}{c}203 \\
46 \mathrm{~A} \\
202 \\
32 \mathrm{~A}\end{array}$ & $\mid \begin{array}{l}\text { May 27, } 1936 \\
\text { June 23, } 1935 \\
\text { May 27, } 1936 \\
\text { May 26, } 1935\end{array}$ & $\begin{array}{c}m g m . \\
30 \\
18 \\
15 \\
12\end{array}$ & \begin{tabular}{c|}
$c c$. \\
3550 \\
2985 \\
3020 \\
2945
\end{tabular} & $\begin{array}{c}c c . \\
3160 \\
2720 \\
2880 \\
2680\end{array}$ & $\begin{array}{l}c c . \\
220 \\
180 \\
220 \\
185\end{array}$ & $\begin{array}{l}6.07 \\
5.63 \\
7.12 \\
5.13\end{array}$ & $\begin{array}{l}5.61 \\
5.28 \\
6.48 \\
4.72\end{array}$ & $\begin{array}{l}5.04 \\
3.82 \\
5.83 \\
3.50\end{array}$ & $\begin{array}{l}4.70 \\
3.33 \\
5.16 \\
2.72\end{array}$ & $\begin{array}{l}4.11 \\
3.12 \\
3.89 \\
2.18\end{array}$ & $\begin{array}{l}3.25 \\
2.73 \\
3.37 \\
2.12\end{array}$ & $\begin{array}{l}2.69 \\
2.66 \\
2.71 \\
1.90\end{array}$ & $\begin{array}{l}2.26 \\
2.49 \\
2.64 \\
2.16\end{array}$ & $\begin{array}{l}2.06 \\
2.14 \\
2.43 \\
2.11\end{array}$ & \begin{tabular}{|l|}
1.89 \\
1.83 \\
2.07 \\
2.08
\end{tabular} & $\begin{array}{c}\text { per cent } \\
52.5 \\
49.8 \\
56.0 \\
45.0\end{array}$ & $\begin{array}{r}1.365 \\
1.083 \\
.829 \\
.760\end{array}$ & $\begin{array}{c}\text { per cent } \\
\text { per hour } \\
2.75 \\
2.54 \\
2.92 \\
2.15\end{array}$ & $\begin{array}{c}\text { per cent } \\
44.1 \\
40.7 \\
46.8 \\
34.5\end{array}$ \\
\hline \multicolumn{2}{|c|}{ Average } & & & & & & & & & & & 2.44 & 2.39 & 2.19 & 1.97 & 53.3 & & 2.59 & 41.5 \\
\hline
\end{tabular}

of disappearance at various stages of the 24-hour period. Evans Blue leaves the blood stream very slowly and beginning 12 hours after injection the rate of disappearance may be considered constant for the purpose of the determination of control disappearance slopes.

The conformity of dye concentration of samples taken over a 24-hour period in these individuals to a smooth curve indicates that no considerable concentration or dilution of the blood occurs during the resting state. We are unable to attribute any of the slight variations in dye concentration of individual blood samples from the predominant curve to the ingestion of food or water, the elimination of waste products or to sleep.

We have studied the rate of disappearance during 2-hour periods 16 hours after dye injection in 10 normal individuals under basal conditions. For the initial volume determination, 24 to $30 \mathrm{mgm}$. of dye were used and 16 keeping with the finding of a constantly diminishing rate of disappearance over the 24-hour period. We believe these instances are evidence of a circulatory change induced by the taking of serial blood samples.

When blood samples are taken over a period of from thirty to forty minutes through the same needle or by repeated punctures a progressive decrease in the cell volume percentage occurs. Figure 9 shows the average per cent of decrease in hematocrit values taking place over a period of forty minutes, amounting to about 3 per cent, as observed in 105 patients. The rate of decrease is at first rapid, becoming less after about twenty-five minutes. A similar change in hematocrit values and a fall in dye concentration of serum was observed in serial blood samples taken in the 10 cases listed in Table IV, in general equal to the percentage of decline in hematocrit values. This decline in dye concentration was of such a degree that it could not 
TABLE IV

Disappearance from the blood stream of intravenously injected Evans Blue in 10 normal males 16 hours after injection

\begin{tabular}{|c|c|c|c|c|c|c|c|c|c|}
\hline $\begin{array}{c}\text { Experiment } \\
\text { number } \\
.\end{array}$ & Date & $\begin{array}{c}\text { Amount } \\
\text { of Evans } \\
\text { Blue given } \\
\text { intra- } \\
\text { venously }\end{array}$ & $\begin{array}{l}\text { Initial } \\
\text { plasma } \\
\text { volume }\end{array}$ & $\underset{\Delta D}{\text { Initial }}$ & $\underset{16 \text { hours }}{\Delta D}$ & $\begin{array}{l}\text { Elapsed } \\
\text { time } \\
\text { since } \\
\text { injection }\end{array}$ & $\begin{array}{l}\text { Disap- } \\
\text { pearance } \\
\text { since } \\
\text { injection }\end{array}$ & $\begin{array}{c}\text { Average } \\
\text { disap- } \\
\text { pearance } \\
\text { from } \\
\text { time of } \\
\text { injection }\end{array}$ & $\begin{array}{c}\text { Deter- } \\
\text { mined } \\
\text { from } \\
\text { disap- } \\
\text { pearance } \\
\text { slope }\end{array}$ \\
\hline $\begin{array}{l}135 \\
128 \\
196 \\
148 \\
200 \\
199 \\
202 \\
219 \\
225 \\
229\end{array}$ & $\begin{array}{lr}\text { November } & 13,1935 \\
\text { December } & 12,1935 \\
\text { January } & 8,1936 \\
\text { January } & 29,1936 \\
\text { April } & 1,1936 \\
\text { May } & 27,1936 \\
\text { July } & 1,1936 \\
\text { July } & 8,1936 \\
\text { July } & 22,1936 \\
\text { July } & 29,1936\end{array}$ & $\begin{array}{c}m g m . \\
30 \\
30 \\
30 \\
30 \\
24 \\
24 \\
30 \\
30 \\
30 \\
30\end{array}$ & $\begin{array}{c}c c . \\
2970 \\
2820 \\
2760 \\
2380 \\
2135 \\
3230 \\
3030 \\
3040 \\
2485 \\
3260\end{array}$ & $\begin{array}{l}1.703 \\
1.740 \\
1.805 \\
2.060 \\
1.856 \\
1.263 \\
1.600 \\
1.625 \\
1.990 \\
1.520\end{array}$ & $\begin{array}{r}1.101 \\
1.110 \\
.982 \\
1.293 \\
1.086 \\
.796 \\
.830 \\
1.039 \\
1.110 \\
.855\end{array}$ & $\begin{array}{l}15^{\circ} 20^{\prime} \\
15^{\circ} 48^{\prime} \\
16^{\circ} 19^{\prime} \\
16^{\circ} 19^{\prime} \\
15^{\circ} 27^{\prime} \\
14^{\circ} 42^{\prime} \\
16^{\circ} 10^{\prime} \\
17^{\circ} 26^{\prime} \\
17^{\circ} 26^{\prime} \\
17^{\circ} 28^{\prime}\end{array}$ & $\begin{array}{l}\text { per cent } \\
35.3 \\
36.1 \\
45.6 \\
37.1 \\
41.5 \\
36.9 \\
48.1 \\
35.7 \\
44.2 \\
43.7\end{array}$ & 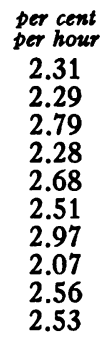 & $\begin{array}{c}\text { per cent } \\
\text { per hour } \\
2.48 \\
1.89 \\
2.57 \\
2.42 \\
1.48 \\
2.20 \\
2.40 \\
1.83 \\
2.16 \\
2.56\end{array}$ \\
\hline Average & & & & & & & 40.43 & 2.50 & 2.20 \\
\hline
\end{tabular}

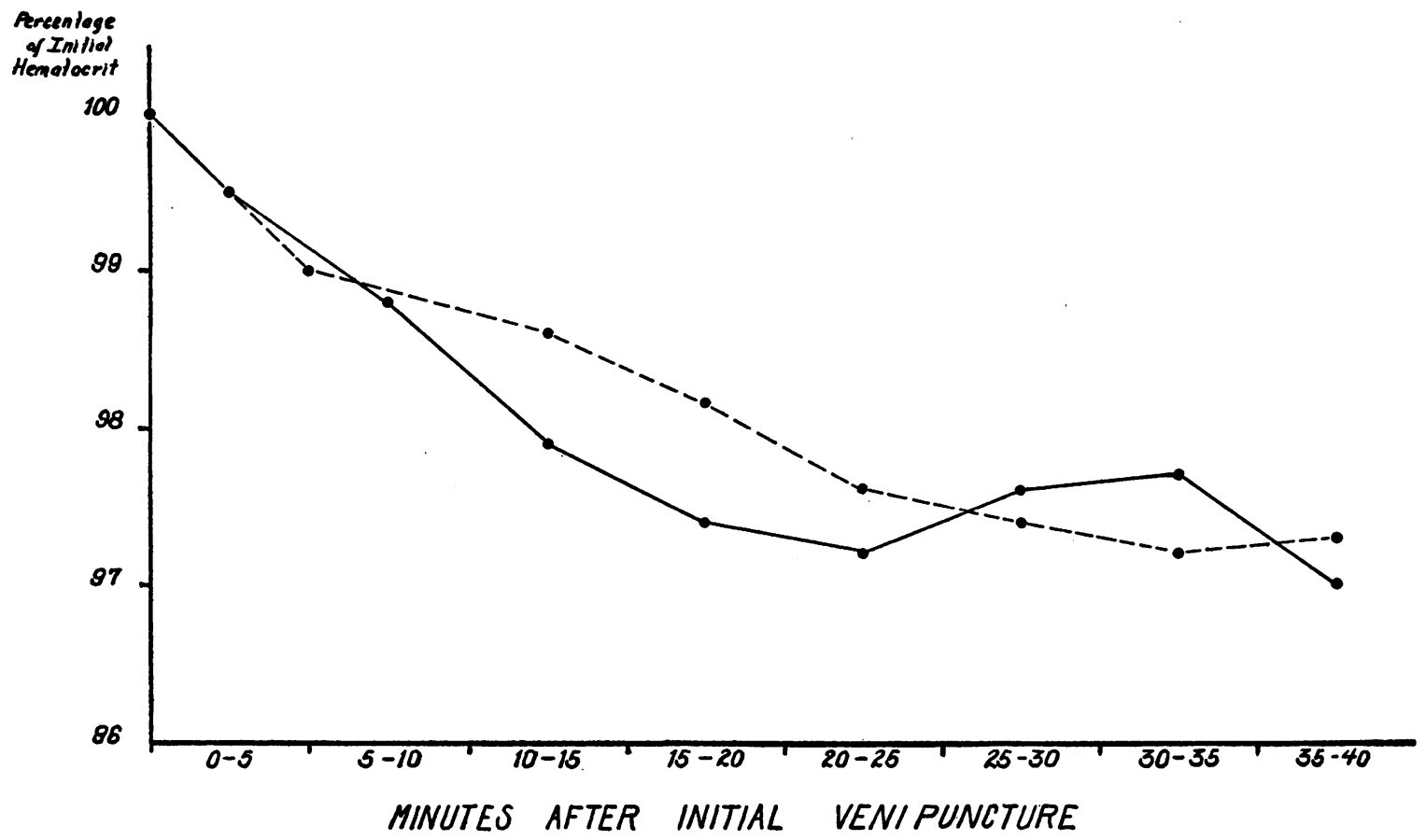

Fig. 9. Decline in Hematocrit Values Observed on Repeated Blood Sampling

The solid line represents the average value of hematocrits, grouped in five minute periods, obtained during routine blood volume determinations in 60 patients with normal cardiovascular systems; the broken line the average values obtained in 55 decompensated cardiac patients. The initial hematocrit is taken as 100 per cent in each case, and all samples were taken without stasis, either through the same needle or by repeated puncture. The average fall in hematocrits, 3 per cent, is beyond the limit of error of the technique and greater than can be accounted for by blood withdrawn or the small amounts of saline (30 cc. in 40 minutes) injected to prevent clotting in the needle. 
represent actual disappearance of the dye from the blood stream since it was in excess of the average rate of clearance prevailing during a corresponding period of the 24-hour curves shown above. We have observed the same phenomenon to occur in dogs (22). The effect of this decline in dye values tends to make the disappearance slope constructed from serial samples falsely steep. This is clearly illustrated in two of the subjects in whom dye clearance was followed for 24 hours. Several groups of serial samples were taken during the 24-hour period and in each instance, as seen in Figure 8, the slopes constructed from each group of samples are steeper than the corresponding portion of the 24-hour curve.

We do not believe these declines in hematocrit values and dye concentrations are due either to stasis, because of the precautions taken to avoid it; or to the injection of saline between withdrawals, since a similar condition obtains when a separate venipuncture is made for each sample. A sudden dilution of the circulating volume as a response to pain or hemorrhage would result in a decrease in both cell volume per cent and dye concentration but further studies indicate that the opposite condition, namely, a decrease in the circulating volume of both red cells and plasma, occurs. When repeated determinations are made in the same individual at short intervals, successive plasma volumes tend to differ from the initial volume, the difference being greater than can be accounted for by blood sampling. The percentage of change in plasma volume equals the percentage of change in the value of hematocrits taken during that volume determination. Results in three experiments illustrating this parallel in plasma volume change and hematocrit values are given in Table $\mathrm{V}$. These findings are in keeping with the observations of Hemingway, Scott and Wright (23), who noted a similar drop in hemoglobin values and dye concentration of successive samples taken after injections of water blue in dogs; and of Chanutin, Smith and Mendel (24), who observed a progressive fall in hemoglobin values on repeated sampling.

This reaction is transient, and the volume of circulating plasma and red cells tends to return to the initial level, since the hematocrit and dye concentration values tend to rise towards the end
TABLE $\mathbf{d} \mathbf{V}$

Changes in plasma, red cell and total blood volume and hematocrit values in repeated volume determinations in the same individual at short intervals

\begin{tabular}{|c|c|c|c|c|c|c|}
\hline Sub- & $\begin{array}{c}\text { Number } \\
\text { of volume } \\
\text { deter- } \\
\text { mination }\end{array}$ & $\begin{array}{c}\text { Time } \\
\text { between } \\
\text { dye } \\
\text { injections }\end{array}$ & $\begin{array}{l}\text { Plasma } \\
\text { volume }\end{array} \mid$ & $\begin{array}{c}\text { Change } \\
\text { from } \\
\text { initial } \\
\text { value }\end{array}$ & $\underset{\text { tocrit }}{\text { Hema- }}$ & $\begin{array}{l}\text { Change } \\
\text { from } \\
\text { initial } \\
\text { value }\end{array}$ \\
\hline W.A.E. & $\begin{array}{l}1 \\
2 \\
3\end{array}$ & $\begin{array}{l}0 \\
27 \text { minutes } \\
54 \text { minutes }\end{array}$ & \begin{tabular}{c|}
$c c$. \\
3140 \\
3000 \\
3065
\end{tabular} & $\begin{array}{r}\text { per cent } \\
-4.5 \\
-2.7\end{array}$ & $\begin{array}{l}44.6 \\
42.5 \\
43.0\end{array}$ & $\begin{array}{l}\text { per cent } \\
-4.6 \\
-3.6\end{array}$ \\
\hline W. C. & $\begin{array}{l}1 \\
2\end{array}$ & $\stackrel{0}{27}$ minutes & $\begin{array}{l}3660 \\
3510\end{array}$ & -4.1 & $\begin{array}{l}45.9 \\
43.9\end{array}$ & -4.4 \\
\hline$-W$ & $\begin{array}{l}1 \\
2\end{array}$ & $\begin{array}{l}0 \\
27 \text { minutes }\end{array}$ & $\begin{array}{l}3170 \\
3190\end{array}$ & $\begin{array}{l}0 \\
+0.6\end{array}$ & $\begin{array}{l}41.4 \\
41.4\end{array}$ & 0 \\
\hline
\end{tabular}

of a series of samples. The effect of this reaction on the determination of disappearance slopes can be minimized by taking samples over a sufficient length of time. In our experience, in the long indirect method, control disappearance slopes should be based on at least five samples taken at 20 to 30 minute intervals. The optimal time after dye injection is from 12 to 20 hours, when changes in the hourly rate of disappearance are negligible and the dye concentration in the blood is still high enough for accurate spectrophotometric readings.

Changes in the pigment content of serum during the experimental period may affect the accuracy of indirectly calculated plasma volumes to some extent.

The average optical density at $6200 \mu \mu$ in cells of $20 \mathrm{~mm}$. depth of dye free serum as determined in 20 normal men is about 0.1000 . Since the amount of dye injected in the indirect method is such that optical densities in the neighborhood of 1.00 are obtained during the experimental period, an increase of 10 per cent in the optical density of the serum itself (due to increase in pigment content), would result in an increase of only 1 per cent in the $\Delta D$ of the dyed serum read against the initial dye free sample. Errors arising from this source can best be avoided by maintaining subjects on fat free meals and are so slight as to be negligible.

We have made extensive studies by the indirect method of changes in plasma and total blood volume occurring during diuresis, fever, exercise and surgical operations. These conditions are accompanied by marked physiological dis- 
turbances which might alter the rate of clearance from the blood stream. No method of quantitating such changes is available. However, since the experimental period selected is one during which the rate of dye disappearance is practically constant and very slow, changes in disappearance rate during an experiment will affect the accuracy of calculations of plasma volume based on the dye concentration of serum samples taken during the experiment, very little. In over 30 experiments of this type, plasma volumes calculated from the dye concentration of the sample taken just prior to the injection of dye for the repeated volume determination agreed within 5 per cent with the redetermined plasma volume.

\section{SUMMARY AND CONCLUSIONS}

(1) The application of a method for determining the plasma and total blood volume employing the blue dye Evans Blue and the spectrophotometer to the investigation of clinical problems is described.

(2) Colorimetric errors inherent in earlier methods due to turbidity of plasma, lipemia, residual dye in repeated determinations and hemolysis of samples are minimized by the use of the spectrophotometer, and a spectrophotometric method of correcting for hemolysis is described.

(3) Errors due to variations in dye mixing time occurring in different clinical states, and possible dilution of injected dye by lymph are eliminated by calculating the plasma volume from a value obtained by extrapolation of the slope of disappearance of the dye from the blood stream, as determined by multiple samples taken over a period of at least thirty minutes after dye injection, to the time of injection.

(4) By the "direct" method of repeated single determinations, volume changes of clinical significance in the same individual can be reliably measured at frequent intervals. By the "indirect method" changes in volume can be continuously followed for periods of from a few minutes to several hours.

(5) Certain factors affecting the accuracy of the indirect method are discussed. A physiological response to serial blood sampling consisting of a transient and variable decrease in the circulating plasma and red cell volume renders accurate estimation of the rate of disappearance of dye from the blood stream difficult. Experimental procedures may alter the intrinsic color of the serum and rate of dye disappearance.

We wish to express our thanks to Professor Henry A. Christian for many helpful suggestions; to Professor Walter B. Cannon and Professor A. Baird Hastings for the use of spectrophotometers; and to Miss Evelyn Berstein for technical assistance.

\section{BIBLIOGRAPHY}

1. Keith, N. M., Rowntree, L. G., and Geraghty, J. T., A method for the determination of plasma and blood volume. Arch. Int. Med., 1915, 16, 547.

2. Griesbach, W., Eine klinisch brauchbare Methode der Blutmengenbestimmung. Deutsche med. Wchnschr., $1921,47,1289$.

3. Seyderhelm, R., and Lampe, W., Die Blutmengenbestimmung und ihre klinische Bedeutung. Unter besonderer Berücksichtigung der Farbstoffmethode. Ergebn. d. inn. Med. u. Kinderh., 1925, 27, 245.

4. Heilmeyer, L., Das Verhalten des Kongorots zu den Serumkolloiden, zugleich ein methodischer Beitrag zur Blutmengenbestimmung mit Kongorot nach Griesbach. Biochem. Ztschr., 1929, 212, 430.

5. Smith, H. P., Studies on vital staining. I. Some problems in colorimetry. The quantitative analysis of mixtures of colored substances in solution. J. Exper. Med., 1930, 51, 369.

6. Graff, S., and Clarke, H. T., Determination of plasma volume. I. The dye method. Arch. Int. Med., 1931, 48, 808.

7. Smith, H. P., Blood volume studies. II. Repeated determination of blood volume at short intervals by means of the dye method. Am. J. Physiol., 1920, $51,221$.

8. Uhlenbruck, P., and Leyendecker, T., Stufenphotometrische Blut-Plasmamengenbestimmungen bei Herzkranken, normalpersonen und nach sportlichen Anstrengungen. Ztschr. f. klin. med., 1931, 118, 164.

9. Brockmann, H., Ein Beitrag zur Frage der Bestimmung der zirkulierenden Blutmenge beim normalen lebenden menschen mit der Farbstoff-Injektionsmethode, unter Benutzung des Pulfrichschen Stufenphotometers. Ztschr. f. d. ges. exper. Med., 1933, 87, 208.

10. Sunderman, F.W. The measurement of serum volume. J. Biol. Chem. (Proc.), 1935, 109, xci.

11. Gregersen, M. I., Gibson, J. J., and Stead, E. A., Plasma volume determination with dyes, errors in colorimetry; use of the blye dye T-1824. Am. J. Physiol. (Proc.), 1935, 113, 54.

12. Gregersen, M. I., Gibson, J. G., and Stead, E. A. (To be published.) 
13. Dawson, A. B., Evans, H. M., and Whipple, G. H., Blood volume studies. III. Behavior of a large series of dyes introduced into the circulating blood. Am. J. Physiol., 1920, 51, 232.

14. Gibson, J. G., 2nd, A method of determining the blood volume. New England J. Med. (Proc.), 1936, 214, 607.

15. Evans, Wm., Venous pressure. New England J. Med., 1932, 207, 1934.

16. Winternitz, M., Deutsch, J., and Brüll, Z., Eine Klinisch brauchbare Bestimmungsmethode der Blutumlaufszeit mittels Decholininjektion. Med. Klin., 1931, 27, 986.

17. Hooper, C. W., Smith, H. P., Belt, A. E., and Whipple, G. H., Blood volume studies. I. Experimental control of a dye blood volume method. Am. J. Physiol., 1920, 51, 205.

18. Wollheim, E., Die Bestimmung der zirkulierende Blutmenge. Ztschr. f. klin. Med., 1928, 108, 463.

19. Goldbloom, A. A., and Libin, I., Clinical studies in circulatory adjustments. I. Clinical evaluation of studies of circulating blood volume. Arch. Int. Med., 1935, 55, 484.

20. Smith, H. P., The fate of an intravenously injected dye (brilliant vital red) with special reference to its use in blood volume determinations. Bull. Johns Hopkins Hosp., 1925, 36, 325.

21. Gibson, J. G., 2nd, and Gregersen, M. I., Toxicity of two vital dyes used in plasma volume determinations. Am. J. Physiol. (Proc.), 1935, 113, 50.

22. Evans, Wm. A., Jr., and Gibson, J. G., 2nd. The blood volume in diuresis. Am. J. Physiol., 1937, 118, 251.

23. Hemingway, A., Scott, F. H., and Wright, H. N., The kinetics of the elimination of the dye water blue from dog plasma after intravenous injection. Am. J. Physiol., 1935, 112, 56.

24. Chanutin, A., Smith, A. H., and Mendel, L. B., Factors concerned in blood volume regulation. Am. J. Physiol., 1924, 68, 444. 